\title{
Pengaruh perbedaan lama waktu pemberian Spirulina platensis dalam ransum terhadap profil darah merah ayam Broiler
}

\section{The effect of feeding duration of Spirulina platensis in ration on Red Blood cells Profile of Broiler chicken}

\author{
Fuadhy Wahyu Fahmi*, Endang Widiastuti dan Sugiharto Sugiharto \\ Departemen peternakan, Fakultas Peternakan dan Pertanian Universitas Diponegoro, Semarang \\ Jl.drh. R. Soejono Koesoemowardojo, Tembalang, Kota Semarang. Kode Pos 50275
}

Submitted : 09 September 2017, Accepted : 30 October 2017

\begin{abstract}
ABSTRAK: Penelitian ini bertujuan untuk mengkaji pengaruh lama waktu pemberian Spirulina platensis. sebagai prebiotik terhadap profil darah merah ayam broiler. Materi yang digunakan pada penelitian ini adalah 240 ekor day old chick (DOC) ayam broiler dengan bobot awal rata-rata 42,015 $\pm 0,219$ g. Percobaan dirancang berdasar Rancangan Acak Lengkap (RAL) dengan 4 perlakuan dan 5 ulangan. Perlakuan yang diterapkan yaitu T0 (Pakan Basal $+0,04 \%$ Zinc Bacitracin), T1 (Pakan Basal $+1 \%$ Spirulina platensis selama 7 hari pemberian), T2 (Pakan Basal $+1 \%$ Spirulina platensis selama 21 hari pemberian) dan T3 (Pakan Basal $+1 \%$ Spirulina platensis selama 35 hari pemberian). Variabel yang diukur meliputi total eritrosit, kadar hemoglobin, persentase hematokrit, serta nilai indeks eritrosit (MCV, MCH, MCHC). Data dianalisis dengan uji ragam (uji F) dan apabila terdapat perbedaan nyata maka dilanjutkan dengan uji wilayah ganda Duncan. Hasil penelitian menunjukkan adanya pengaruh $(\mathrm{P}<0,05)$ antar perlakuan terhadap rataan total eritrosit, serta tidak ada pengaruh $(\mathrm{P}>0,05)$ antar perlakuan terhadap kadar hemoglobin, persentase hematokrit, serta nilai indeks eritrosit ( $\mathrm{MCV}, \mathrm{MCH}, \mathrm{MCHC})$. Kesimpulan dari penelitian ini yaitu, pemberian Spirulina platensis selama 35 hari dalam ransum dapat menurunkan total eritrosit ayam broiler. Pemberian $S$. platensis sebagai prebiotik yang diberikan selama 7 atau 21 hari pemeliharaan memberikan hasil yang sama dengan pemberian AGPs (Antibiotics Growth Promoters) dilihat dari profil darah merah ayam broiler.
\end{abstract}

Kata kunci: Sel darah merah, ayam broiler, Spirulina platensis, prebiotic

ABSTRACT: The study was conducted to evaluate the effect of duration feeding of Spirulina platensis as a prebiotic in ration on the red blood cells of broiler chickens. The material used in this study was 240 day old chick (DOC) with average of initial weight $42.015 \pm 0.219 \mathrm{~g}$. The experiment was designed based on Completely Randomized Design (CRD) with 4 treatments and 5 replications. The treated treatments were T0 (Feed Basal $+0.04 \%$ Zinc Bacitracin), T1 (Basal diet $+1 \%$ Spirulina platensis for 7 days administration), T2 (Basal diet $+1 \%$ Spirulina platensis for 21 days of administration) and T3 (Feed Basal $+1 \%$ Spirulina platensis for 35 days of administration). Measured variables include total erythrocytes, hemoglobin, percentage of hematocrit, and erythrocyte index values $(\mathrm{MCV}, \mathrm{MCH}, \mathrm{MCHC})$. Data were analyzed by variance test (F test) and if there was a significant difference then continued with Duncan's multiple range test. The results showed that there was significant differences $(\mathrm{P}<0.05)$ between treatments on total erythrocytes, and no significant differences $(\mathrm{P}>0.05)$ between treatments on hemoglobin levels, hematocrit percentage, and erythrocyte index values (MCV, MCH, MCHC). It concluded that the feeding of Spirulina platensis for 35 days in ration can reduce total broiler erythrocytes and feeding S. platensis as a prebiotic given for 7 or 21 days of administration gives the same result as giving AGPs (Antibiotics Growth Promoters) seen from the broiler's red blood profile.

Keywords: Red blood cells, broiler chicken, Spirulina platensis, prebiotic

*Corresponding author: fuad.fuadhy@gmail.com

DOI: 10.21776/ub.jiip.2017.027.03.07 


\section{PENDAHULUAN}

Penggunaan antibiotik sebagai growth promotor telah lama dilakukan oleh para peternak untuk memacu pertumbuhan ayam broiler. Namun penggunaan antibiotik sebagai growth promotor telah menimbulkan perdebatan terkait dengan residu antibiotik pada produk ayam broiler yang dapat menyebabkan resistensi mikroorganisme patogen dan berdampak buruk bagi kesehatan manusia sebagai konsumen. Banyak studi dilakukan untuk mendapatkan bahan alternatif yang dapat menggantikan fungsi antibiotik pada ternak salah satunya yaitu prebiotik. Prebiotik bersifat menstimulasi pertumbuhan mikroba nonpatogenik pada saluran pencernaan sehingga diharapkan penyerapan nutrisi oleh saluran pencernaan menjadi lebih baik dan produktivitas menjadi optimal (Haryati, 2011). Salah satu bahan yang berpotesi sebagai prebiotik yaitu Spirulina platensis (Gupta et al., 2017).

S. platensis memiliki kandungan oligosakarida berupa mannosa dan rhamnosa yang diketahui dapat menstimulasi pertumbuhan mikroba nonpatogenik (Gupta et al., 2017). Bhowmik et al. (2009) melaporkan bahwa $S$. platensis dapat menstimulasi pertumbuhan bakteri asam laktat (BAL) dan menghambat pertumbuhan bakteri patogen sehingga status kesehatan ayam menjadi lebih baik. Dari sisi produktivitas, Lokapirnasari dkk. (2011) melaporkan bahwa pengunaan $1.5 \% \mathrm{~S}$. platensis pada ransum menunjukkan adanya peningkatan proses pencernaan dan metabolisme tubuh sehingga performa ternak yang dihasilkan lebih baik.

Produktivitas ayam broiler sangat dipengaruhi oleh kondisi darah dalam tubuhnya. Eritrosit merupakan salah satu komponen dalam darah yang mempunyai fungsi sejalan dengan hemoglobin yang berperan dalam pertukaran gas $\left(\mathrm{O}_{2}\right.$ dan
$\left.\mathrm{CO}_{2}\right)$ dan distribusi oksigen $\left(\mathrm{O}_{2}\right)$ ke dalam sel yang diperlukan untuk proses metabolisme. Eritrosit dapat menjadi indikator status kecukupan nutrisi dalam tubuh. Hal tersebut karena eritrosit mengandung hemoglobin yang membawa $\mathrm{O}_{2}$ yang jumlahnya sejalan dengan tinggi rendahnya nutrisi yang diserap oleh tubuh untuk proses metabolisme. Secara umum ada bebrapa factor yang dapat memengaruhi jumlah eritrosit di dalam tubuh antara lain yaitu kualitas pakan, umur, serta jenis kelamin (Yuniwarti, 2015).

Studi yang dilakukan oleh Alonge et al. (2017) melaporkan bahwa penggunaan prebiotik berupa Mannan oligosaccharides (MOS, 500 ppm) dalam ransum menghasilkan jumlah eritrosit yang sama dibandingkan dengan penggunaan growth promotor lain (Oxytetracycline dan GRO-UPTM/probiotik). Terkait dengan $S$. platensis, jenis mikrolaga tersebut mempunyai peran aktif dalam biosintesis enzim metabolik seperti cytochromes, superoxide dismutase and glutathione reductase sehingga terjadi peningkatan proses metabolisme di dalam tubuh ternak (Jamil et al., 2015).

Penggunaan $S$. platensis sebagai feed additive telah terbukti memberikan efek positif terhadap produktivitas akan tetapi biasanya pemberian dilakukan selama masa pemeliharaan $( \pm 35$ hari). Dengan harga $S$. platensis yang relatif lebih mahal dibandingkan dengan antibioik maka akan sangat mempengaruhi efisiensi biaya produksi yang dikeluarkan dari suatu usaha peternakan. Oleh karena itu lama waktu pemberian $S$. platensis sebagai prebiotik perlu dikaji agar dicapai hasil yang lebih efisien.

Tujuan penelitian ini yaitu untuk mengkaji pengaruh lama waktu pemberian $S$. platensis sebagai prebiotik terhadap profil darah merah ayam broiler. Manfaat dari penelitian ini yaitu dapat memberikan

DOI: 10.21776/ub.jiip.2017.027.03.07 
dasar tentang lama dan fase efektif penggunaan prebiotik dalam ransum untuk menstimulasi pertumbuhan mikrobia saluran pencernaan ayam broiler.

\section{MATERI DAN METODE}

Penelitian ini dilaksanakan pada bulan Juli-Agustus 2017. Materi yang digunakan pada penelitian ini yaitu Day Old Chick (DOC) ayam broiler berstrain Lohmann sebanyak 240 ekor dengan bobot awal rata-rata 42,015 $\pm 0,219 \mathrm{~g}$. Peralatan yang digunakan meliputi kandang koloni dengan ukuran $1 \times 1 \mathrm{~m}$ berjumlah 20 petak, ransum, peralatan pakan dan minum, instansi listrik, timbangan, thermometer dan hygrometer, alat tulis dan peralatan penelitian lainnya. Metode yang dilakukan dalam penelitian ini meliputi penentuan rancangan percobaan, pelaksanaan penelitian, serta analisis data.

\section{Rancangan percobaan}

Percobaan yang dilakukan menggunakan Rancangan Acak Lengkap (RAL) yang terdiri dari 4 perlakuan dan 5 ulangan. Setiap ulangan terdiri dari 12 ekor. Perlakuan yang diterapkan meliputi:
T0 = Pakan Basal + 0,04\% Zinc Bacitracin selama 35 haripemberian

$\mathrm{T} 1$ = Pakan Basal $+1 \%$ S.platensis selama 7 hari pemberian

$\mathrm{T} 2$ = Pakan Basal $+1 \%$ S.platensis selama 21 hari pemberian

$\mathrm{T} 3$ = Pakan Basal + 1\% S.platensis selama 35 hari pemberian

\section{Pelaksanaan penelitian}

Tahap persiapan dilakukan dengan persiapan kandang berupa membersihkan kandang dan lingkungan sekiter, pengapuran, desinfeksi kandang dan dilanjutkan fumigasi dengan menggunakan Formalin dan $\mathrm{KMnO}_{3}$.

Masa Pemeliharaan dilakukan selama 35 hari. Ransum perlakuan diberikan dari hari pertama pemeliharaan dengan menyesuaikan kebutuhan konsumsi ayam perharinya. Air minum diberikan secara ad libitum. Pengukuran suhu dan kelembaban di dalam maupun di luar kandang. Vaksinasi tetes mata dilakukan pada hari ke-4 dan air munim pada hari ke18 masa pemeliharaan. Ransum yang diberikan disajikan pada (Table 1.).

DOI: 10.21776/ub.jiip.2017.027.03.07 
Tabel 1. Bahan Pakan, Persentase Penggunaan Serta Kandungan Nutrisi Ransum

\begin{tabular}{|c|c|c|c|c|}
\hline \multirow{2}{*}{ Bahan Pakan } & \multicolumn{4}{|c|}{ Persentase Penggunaan Bahan dalam Ransum } \\
\hline & T0 & T1 & T2 & T3 \\
\hline $\mathrm{CPO}$ & 3,50 & 3,50 & 3,50 & 3,50 \\
\hline Dedak & 4,45 & 4,45 & 4,45 & 4,45 \\
\hline Jagung & 45,5 & 45,5 & 45,5 & 45,5 \\
\hline Tepung Gandum & 10,0 & 10,0 & 10,0 & 10,0 \\
\hline Tepung Roti & 5,00 & 5,00 & 5,00 & 5,00 \\
\hline MBM & 2,80 & 2,80 & 2,80 & 2,80 \\
\hline CFM & 2,00 & 2,00 & 2,00 & 2,00 \\
\hline CGM & 3,60 & 3,60 & 3,60 & 3,60 \\
\hline DDGS & 3,00 & 3,00 & 3,00 & 3,00 \\
\hline SBM & 17,0 & 17,0 & 17,0 & 17,0 \\
\hline Elthreonin & 0,08 & 0,08 & 0,08 & 0,08 \\
\hline Lisin & 0,55 & 0,55 & 0,55 & 0,55 \\
\hline Metionin & 0,37 & 0,37 & 0,37 & 0,37 \\
\hline Tepung Tulang & 1,50 & 1,50 & 1,50 & 1,50 \\
\hline Garam & 0,15 & 0,15 & 0,15 & 0,15 \\
\hline Premix & 0,50 & 0,50 & 0,50 & 0,50 \\
\hline Total & 100 & 100 & 100 & 100 \\
\hline Zinc Bacitracin & 0,04 & - & - & - \\
\hline Spirulina platensis & - & 1 & 1 & 1 \\
\hline \multicolumn{5}{|l|}{ Kandungan nutrisi pakan: } \\
\hline Energi Metabolis (kkal/kg)* & 3.510 & 3.510 & 3.510 & 3.510 \\
\hline Bahan Kering $(\%)^{* *}$ & 89,64 & 89,64 & 89,64 & 89,64 \\
\hline Protein Kasar (\%)** & 21,93 & 21,93 & 21,93 & 21,93 \\
\hline Lemak Kasar (\%)** & 6,40 & 6,40 & 6,40 & 6,40 \\
\hline Serat Kasar (\%)** & 5,620 & 5,620 & 5,620 & 5,620 \\
\hline $\mathrm{Abu}(\%)^{* *}$ & 6,39 & 6,39 & 6,39 & 6,39 \\
\hline
\end{tabular}

Keterangan:

(*) : Energi Metabolis (EM) dihitung berdasarkan rumus Balton (1967).

(**) : Hasil Analisis di Laboratorium Ilmu Nutrisi dan Pakan, Universitas Diponegoro.

Pengambilan data dilakukan ketika ayam berumur 32 hari. Pengambilan darah dilakukan dengan mengambil satu ekor ayam broiler secara acak dari setiap unit. Darah diambil melalui vena brachialis sebanyak $3 \mathrm{ml}$ dengan menggunakan spuit ukuran $3 \mathrm{cc}$. Darah yang sudah diambil selanjutnya dimasukkan ke dalam vacutainer yang berisi Ethylen diamine tetra aceticacid (EDTA) dan dimasukkan ke dalam coller box. Darah selanjutnya dianalisis menggunakan PRIMA $^{\odot}$ fully-auto Hematology Analizer.

Pengukuran total eritrosit dan hematokrit diukur dengan menggunakan metode Electrical Impedance dengan menggunakan alat Hematology Analyzer. Pengukuran kadar hemoglobin, diukur dengan menggunakan metode Cyanide Free Hemoglobin Spectrophotometry dengan menggunakan alat Hematology 
Analyzer. Indeks darah merah (MCV, $\mathrm{MCH}$ dan MCHC), indeks darah merah diperoleh dengan menggunakan rumus berikut (Fitrohdin dkk., 2014):

Mean corpuscular volume (MCV)

$$
\operatorname{MCV}(\mathrm{fl})=\frac{\text { Hematokrit } \mathrm{x} 10}{\text { Eritrosit Total }}
$$

Mean corpuscular haemoglobin (MCH)

$$
\mathrm{MCH}(\mathrm{pg})=\frac{\text { Hemoglobin } \mathrm{x} 10}{\text { Eritrosit Total }}
$$

Mean corpuscular haemoglobin concentration (MCHC)

$$
\operatorname{MCHC}(\%)=\frac{\text { Hemoglobin } \times 100}{\text { Hematokrit }}
$$

Analisis data dilakukan dengan analisis ragam (ANOVA) dan uji $\mathrm{F}$, apabila terdapat perbedaan nyata maka dilanjutkan dengan uji wilayah ganda Duncan.

\section{HASIL DAN PEMBAHASAN}

Rataan total eritrosit, hemoglobin, hematokrit, serta indeks eritrosit ayam broiler dengan perbedaan lama waktu pemberian $S$. platensis sebagai prebiotik dibandingkan dengan antibiotik disajikan pada Tabel 2.

Tabel 2. Rataan total eritrosit, kadar hemoglobin, persentase hematokrit dan nilai indeks eritrosit ayam broiler

\begin{tabular}{lcccc}
\hline \multirow{2}{*}{\multicolumn{1}{c}{ Variabel }} & \multicolumn{4}{c}{ Perlakuan } \\
\cline { 2 - 5 } & T0 & T1 & T2 & T3 \\
\hline Total Eritrosit & $2,34 \pm 0,20^{\mathrm{a}}$ & $2,33 \pm 0,19^{\mathrm{a}}$ & $2,36 \pm 0,06^{\mathrm{a}}$ & $1,98 \pm 0,31^{\mathrm{b}}$ \\
(juta/mm $^{3}$ ) & $9,98 \pm 0,78$ & $10,12 \pm 0,76$ & $10,18 \pm 0,34$ & $8,70 \pm 1,33$ \\
Hemoglobin (g/dL) & $30,68 \pm 3,81$ & $31,12 \pm 2,72$ & $31,64 \pm 0,50$ & $26,98 \pm 3,86$ \\
Hematokrit (\%) & $130,94 \pm 6,53$ & $133,80 \pm 1,33$ & $134,20 \pm 1,84$ & $136,90 \pm 3,74$ \\
MCV (fl) & $42,62 \pm 1,42$ & $43,48 \pm 1,45$ & $43,04 \pm 0,43$ & $44,02 \pm 2,28$ \\
MCH (pg) & $32,66 \pm 2,00$ & $32,50 \pm 1,04$ & $32,10 \pm 0,66$ & $32,18 \pm 1,35$ \\
MCHC (g/dL) &
\end{tabular}

Keterangan: Superskrip yang berbeda pada baris yang sama menunjukkan adanya perbedaan nyata $(\mathrm{P}<0,05)$. T0 (Pakan Basal $+0,04 \%$ Zinc Bacitracin $), \mathrm{T} 1$ (Pakan Basal $+1 \%$ S. platensis selama 7 hari pemberian), T2 (Pakan Basal + $1 \%$ S. platensis selama 21 hari pemberian) dan T3 (Pakan Basal $+1 \% S$. platensis selama 35 hari pemberian).

\section{Gambaran eritrosit}

Berdasarkan analisis statistika tabel 2 menunjukkan adanya pengaruh nyata $(\mathrm{P}<0,05)$ total eritrosit ayam broiler pada pemberian $S$. platensis selama 35 hari. Rata-rata jumlah total eritrosit yang dihasilkan pada penelitian ini berkisar antara $1,98-2,3610^{6} / \mu$ L. Perlakuan T3 (pemberian $S$. platensis selama 35 hari) memiliki rataan total eritrosit yang lebih rendah dari T0, T1 dan T2, akan tetapi masih dalam batas kisaran normal eritrosit pada ayam broiler. Jumlah total eritrosit normal pada ayam broiler yaitu berkisar 2,0 - 3,0 x $10^{6} / \mu \mathrm{L}$ (Mangkoewidjojo dan Smith, 1988; Iriyanti dan Suhermiyati, 2015). Rendahnya kadar eritrosit pada T3 dimungkinkan karena terganggunya proses eritropoesis (pembentukan 
eritrosit) sehingga berpengaruh pada total eritrosit dalam darah. Seperti yang telah diketahui bahwa S.platensis mengandung bahan beracun dosis kecil yaitu hepatoxin berupa microcystin dan jika dikonsumsi dalam konsentrasi berlebih maka akan berbahaya bagi tubuh manusia maupun hewan (Christawardana dan Hadiyanto, 2013). Microcystin merupakan jenis peptida siklik nonribosomal yang terkandung pada semua Cyanobacteria yang dapat menyebabkan kerusakan pada hati (Butler et al., 2009; Drobac et al., 2013). Seperti yang telah diketahui bahwa eritropoesis terjadi di dalam sumsum tulang merah (Medula osseum), hati dan limpa, sehingga kesehatan hati sangat berpengaruh terhadap proses eritropoesis.

\section{Hemoglobin}

Berdasarkan analisis statistika menunjukkan tidak adanya pengaruh nyata $(\mathrm{P}>0,05)$ pada setiap perlakuan terhadap kadar hemoglobin ayam broiler. Rataan kadar hemoglobin yang dihasilkan pada penelitian ini bersikar antara 8,70 10,18 g/dL. Hasil tersebut sejalan dengan studi yang dilakukan oleh Al-Saad et al. (2014) yang melaporkan bahwa penggunaan beberapa growth promoters (antibiotik, probiotik, prebotik dan asam organik) menghasikan jumlah hemoglobin yang tidak berbeda antar perlakuan. Nilai Hemoglobin hasil penelitian ini masih dalam batas normal kadar hemoglobin yaitu 7,0 - 13,0 g/dL dan mengindikasikan bahwa ayam tersebut dalam kondisi sehat dan oksigen yang cukup (Jain, 1993; Iriyanti dan Suhermiyati, 2015). Hemoglobin (Hb) merupakan salah satu komponen dalam sel darah merah yang mengandung oksigen. Hemoglobin berperan dalam pertukaran gas dan distribusi oksigen dalam sel untuk proses metabolism.
Kecukupan oksigen yang diangkut dalam tubuh dapat dilihat dari jumlah hemoglobin dalam darah. Jumah hemoglobin sejalan dengan jumlah eritrosit dan nutrisi yang diserap oleh tubuh. Swenson (1984) melaporkan bahwa kadar hemoglobin dalam darah dapat turun akibat dari adanya gangguan dalam proses eritropoesis (pembentukan eritrosit).

\section{Hematokrit}

Berdasarkan analisis statistika menunjukkan tidak adanya pengaruh nyata $(\mathrm{P}>0,05)$ antar perlakuan terhadap persentase hematokrit ayam broiler. Rataan persentase hematokrit yang dihasilkan dalam penelitian ini yaitu berkisar antara 26,98 - 31,64\%. Hasil tersebut sejalan dengan studi yang dilakukan oleh Alonge et al. (2017) melaporkan bahwa penggunaan beberapa growth promters (Oxytetracycline, GROUPTM/probiotik dan MOS 500ppm/prebotik) menghasikan jumlah hematokrit yang tidak berbeda antar perlakuan. Nilai hematokrit hasil penelitian ini masih dalam batas normal hematokrit ayam broiler yaitu yaitu 22 35\% (Shituu et al., 2016; Nurwahyuni dkk., 2016). Nilai hematokrit juga dipengaruhi oleh temperatur lingkungan. Peningkatan kadar hematokrit akan terjadi apabila adanya peningkatan hemokonsentrasi akibat dari kadar sel darah yang meningkat atau turunnya kadar plasma darah (Sutedjo, 2007). Dehidrasi, pendarahan atau edema akibat pengeluaran cairan dari pembuluh darah merupakan indikasi dari adanya peningkatan nilai hematokrit. Nilai hematokrit berhubungan dengan 
viskositas (kekentalan) darah. Peningkatan nilai hematokrit dapat menyebabkan naiknya viskositas (kekentalan) darah sehingga akan menyebabkan perlambatan aliran darah pada kapiler dan meningkatkan kerja jantung (Chunningham, 2002). Pada kondisi Anemia atau kekurangan sel darah merah nilai hematokrit akan rendah. (Wientarsih dkk., 2013). Kerusakan eritrosit, turunnya produksi eritrosit, serta tidak normalnya jumlah dan ukuran eritrosit merupakan penyebab terjadinya anemia (Coles, 1982; Wardhana dkk.,2001).

\section{Indeks eritrosit}

Berdasarkan analisis statistika menunjukkan tidak adanya pengaruh nyata $(\mathrm{P}>0,05)$ antar perlakuan terhadap nilai indeks eritrosit (MCV, $\mathrm{MCH}$ dan MCHC) ayam broiler. Rataan nilai indeks eritrosit yang dihasilkan dalam penelitian ini yaitu MCV berkisar antara 130,94 136,90 fl, MCH 42,62 - 44,02 pg, serta MCHC yaitu 32,10 - 32,66 g/dL. Hasil tersebut sejalan dengan studi yang dilakukan oleh Alonge et al. (2017) melaporkan bahwa penggunaan beberapa growth promoters (Oxytetracycline, GRO-UPTM/probiotik dan MOS 500ppm/prebotik) menghasikan nilai indeks eritrosit yang tidak berbeada antar perlakuan. Nilai indeks eritrosit hasil penelitian ini masih dalam batas normal indeks eritrosit ayam broiler yaitu MCV 90 - 140 fl, MCH $33-47$ pg dan MCHC 26 - 37 g/dL (Jain, 1993; Ulupi dan Ihwantoro, 2014). Penentuan nilai indeks eritrosit ini penting dilakukan untuk mengetahui kondisi fisiologis ternak. Ketidaknormalan nilai MCV, MCH MCHC menunjukkan indikasi adanya anemia yang dapat dipicu oleh kekurangan zat besi, keracunan timbal, kekurangan hormon eritropoietin, kekurangan folat atau kekurangan vitamin B-12 (Ulupi \& Ihwantoro, 2014). Nilai $\mathrm{MCV}, \mathrm{MCH}$, dan MCHC dipengaruhi oleh jumalh eritrsoit, kadar hemoglobin, dan persentase hematokrit (Fitrohdin dkk., 2014).

\section{KESIMPULAN}

Berdasarkan uraian diatas dapat disimpulkan bahwa, pemberian Spirulina platensis selama 35 hari dalam ransum dapat menurunkan total eritrosit ayam broiler. Pemberian S. platensis sebagai prebiotik yang diberikan selama 7 atau 21 hari pemeliharaan memberikan hasil yang sama dengan pemberian AGPs (Antibiotics Growth Promoters) dilihat dari profil darah merah ayam broiler.

\section{SARAN}

S. platensis sebaiknya tidak diberikan selama 35 hari pemeliharaan, hal tersebut untuk mencegah terjadinya penurunan eritrosit dan sekaligus menurunkan biaya produksi.

\section{DAFTAR PUSTAKA}

Alonge, E.O., Eruvbetine, D., Idowu, O.M.O., Obadina A.O., and Olukomaiya, O.O. 2017. Effect of dietary feed additives on haematological and serum biochemical parameters of broiler chickens. Online. J. Anim. Feed Res, 7(1), $18-23$.

Al-Saad., M. Abbod dan A.A. Yones. 2014. Effect of some growth promotors on blood hematology and serum composition of broiler chickens. International Journal of Agricurtural Research. ISSN 
1816-44897/DOI: $\quad 10.3923 / i j a r$. 2014.

Bhowmik, D., Dubey, J., and Mehra, S. 2009. Probotic efficiency of Spirulina platensis-stimulating growth of Lactic Acid Bacteria (LAB). World Journal of Dairy \& Food Sciences, 4(2), 160 - 163.

Bolton, W. 1967. Poultry Nutrition. London: MAFF Bulletin.

Butler, N., Carlisle, J.C., Linville, R., and Washburn, B.2009. Microcystins: A brief overview of their toxicity and effects, with special refrence to fish, wildlife, and livestock. Officer of Environmental Health Hazard Assesment, California.

Christawardana, M dan Hadiyanto, M.M.A.N. 2013. Spirulina platensis: potensinya sebagai bahan pangan fungsional. Jurnal Aplikasi Teknologi Pangan. 2(1): $1-4$.

Coles, E.H.V. 1982. Veterinary Clinical Pathology. 2nd. Ed.W.B. Philadelphia: Saunders Company.

Cunningham, J.G. 2002. Textbook of Veterinary Phisiology. USA: Saunders.

Drobac, D., N. Tokodi, J. Simeunovic, V. Baltic, D. Stanic dan Z. Svircev. 2013. Human exposure to cyanotoxins and their effects on health. 64:305-316. DOI: 10.2478/10004-1254-64-20132320
Fitrohdin, A., Samsi M., dan Indrasanti. D. 2014. Indeks eritrosit pada itik betina Tegal, Mojosari dan Magelang yang pakannya disuplementasi probiotik dengan level berbeda. J. Ilm. Pet, 2(1), 42-51.

Gupta, S., C. Gupta, A.P. Garg and D. Prakash. 2017. Prebiotic efficiency of Blue Green Algae on probiotics microorganisms. Journal of Microbiology and Experimentation. 4(4): 1 - 4 .

Haryati, T. 2011. Probiotik dan prebiotik sebagai pakan imbuhan nonruminansia. Wartazoa, 2(3), $125-132$.

Iriyanti, N dan S. Suhermiyati. 2015. Pemanfaatan susu afkir sebagai probiotik dan aplikasinya dalam pakan terhadap profil hematologis dan lemak darah ayam broiler. Prosiding Seminar Nasional Teknologi dan Agribisnis Peternakan (Seri III): Pengembangan Peternakan Berbasis Sumberdaya Lokal Untuk Menghadapi Masyarakat Ekonomi Asean (MEA). Fakultas Peternakan Universitas Jenderal Soedirman, Purwokerto.

Jain, N. C. 1993. Essential of Veterinary Hematology. Philadelphia: Lea \& Febiger.

Jamil, A.B.M., Akanda, R., Rahman, M., Hossain, A., and Islam. S. 2015. Prebiotic competence of spirulina on the production performance of 
broiler chickens. J. Adv. Vet. Anim. Res, 2(3), 304-309.

Lokapirnasari, W.P., Soewarno, dan Dhamayanti. Y. 2011. Potency of crude Spirulina on protein efficiency ratio in laying hen. Jurnal Ilmiah Kedokteran Hewan, 2(1), $5-8$.

Mangkoewidjojo, S., dan Smith. J. B. 1988. Pemeliharaan, Pembiakan, dan Penggunaan Hewan Percobaan di Daerah Tropis. Jakarta: Universitas Indonesia.

Nurwahyuni, E., E. Sudjarwo dan O. Sjofjan. 2016. Effect of altitudes on blood profile of the broilers. Adv. Anim. Vet. Sci. 4 (3): 122 127.

Shittu, M.D., A.O. Abiola, O.O. Ojebiyi and D.O. Adejumo. 2016. Gut morphologhy and blood profile of finisher broiler fed diets containing dried biscuit dough meal. Int. J. livestock. Res, 6 (9), $49-58$.

Sutedjo, A.Y. 2007. Mengenal Penyakit melalui Hasil Pemeriksaan Laboratorium. Yogyakarta: Amara Books.

Swenson, M.J. 1984. Physiological Properties and Cellular and Chemical Constituents of Blood. Ithaca and London: Duke's Physiology of Domestic Animals. $10^{\text {th }}$ Edition Cornell University Press.

Ulupi, N, dan Ihwantoro. T. 2014. Gambaran darh ayam kampung dan ayam petelur komersial pada kandang terbuka di daerah tropis. Jurnal Ilmu Produksi dan Teknologi Hasil Peternakan, 2(1), $219-223$.

Wardhana A.H., Kencanawati, E, Nurmawati, Rahmaweni, dan Jatmiko. C.B. 2001. Pengaruh pemberian sediaan Patikan Kebo (Euphobia hirta L) terhadap jumlah eritrosit, kadar hemoglobin, dan nilai hematokrit pada ayam yang diinfeksi dengan Eimeria tenella. Jurnal Ilmu Ternak dan Veteriner, 6(2),126133.

Wientarsih, I., Widhyari, S.D., dan Aryanti. T. 2013. Kombinasi imbuhan herbal Kunyit dan zink dalam pakan sebagai alternatif pengobatan Kolibasiolosis pada ayam pedaging. Jurnal Veteriner, 14(3), 327-334.

Yuniwarti, E.Y.W. 2015. Profil darah ayam broiler setelah vaksinasi AI dan pemberian berbagai kadar VCO. Buletin Anatomi dan Fisiologi, 23(1), 38-46. 